\title{
Short Article
}

\section{THE FIRST HUMAN BLOOD TRANSFUSION: PRIORITY DISPUTES}

\author{
by
}

\section{A. RUPERT HALL AND MARIE BOAS HALL*}

IT IS notoriously difficult to deal clearly and accurately with the history of controversy over priority, and the dispute over priority in blood transfusion recently explored by Dr. A. D. Farr in this journal is no exception. ${ }^{1}$ The story has often been told from various points of view: ${ }^{2}$ and we ourselves printed many documents connected with the controversy in our edition of The correspondence of Henry Oldenburg. ${ }^{3}$ The aspect with which Dr. Farr is specifically concerned is the history of human blood transfusion, and he has found it difficult to understand why many of the English felt touchy about this, since the French physician Jean Denis (d. 1704) was clearly the first to practise it. ${ }^{4}$ In particular he has been puzzled by the reaction of Henry Oldenburg, secretary of the Royal Society, to the publication of an English translation of Denis' printed letter (addressed to Hebert de Montmor and dated 25 June 1667 (N.S.)) in what purported to be no. 27 of the Philosophical Transactions. To clarify this matter, and to set the record right in a number of points, it is necessary to consider first, the career of Henry Oldenburg; second, the history and status of the Philosophical Transactions; and finally the pre-history of human blood transfusion and the feelings of nationalism aroused by it.

The article on Oldenburg in the Dictionary of national biography (publ. 1894-5) was by Herbert Rix, assistant secretary of the Royal Society from 1885 to 1896, and is exceptionally full, with references to both manuscript material and secondary sources. Pace Dr. Farr, much more information about Oldenburg's private life is available than is indicated there; further, Rix was far from historically accurate in his understanding of the workings of the Royal Society in the seventeenth century, nor was he

* A. Rupert Hall, M.A., Ph.D., Litt.D., F.B.A., and Marie Boas Hall, A.B., M.A., Ph.D., 14 Ball Lane, Tackley, Oxford OX5 3AG.

'A. D. Farr, 'The first human blood transfusion', Med. Hist., 1980, 24: 143-162.

${ }^{2}$ Dr. Farr relies particularly upon Geoffrey Keynes (editor), Blood transfusion, Bristol, Wright, 1949. The Isis cumulative bibliography, vol. 3, London, Mansell, 1976, lists some fifteen items for the period before 1965. See also, e.g. M. Nicolson, Pepys' Diary and the New Science, Charlottesville, University Press of Virginia, 1965, ch. II, pp. 55-99. In fact Keynes in the first, historical chapter of the book he edited printed facsimiles of pages from Phil. Trans. no. 20 (with the earliest published English work, 1666) and false no. 27, which he says Oldenburg "suppressed". Far more evidence is given by Keynes for English work than Dr. Farr notes.

${ }^{3}$ Especially in vols. III and IV, Madison, Milwaukee, and London, University of Wisconsin Press, 1966 and 1967 , respectively.

4 Ironically Denis was later for some years physician to Charles II. 


\section{Short Article}

inclined to question contemporary or near-contemporary sources. Thus the date of Oldenburg's birth in Bremen is given as 1615?, correcting the earlier, also incorrect date of 1626; as we have tried to show, ${ }^{5} 1618$ or 1619 is the most probable date, based upon the known facts of his education and his declaration at his first marriage in 1663 that he was "aged about 43 yeares". He is known to have graduated from the Gymnasium Illustre of Bremen in 1639 with the degree of Master of Theology, and Rix knew nothing of his career after that until his appointment as agent for the Senate of Bremen to Cromwell in 1653 which brought him to England, except for the rumour, current in 1653, that he had lived in England from 1640-48 and was variously described as in favour with the Parliamentarians and banished as a Royalist. What Oldenburg did in 1640 is not clear, but in 1641 he went from Bremen to Holland with highly commendatory letters of introduction to the learned G. J. Vossius in Leiden. ${ }^{6}$ He subsequently wrote to Vossius with a young man's natural discovery that one needs a job to live; in his case he resolved to combine business with self-education and look for a post as tutor to some young man about to make a European tour. That he succeeded, and that at least some of these young men were English, is clear from surviving drafts of letters to many of them, ${ }^{7}$ and it was presumably from them that he learned the near-perfect English that was to astonish Milton. Possibly he did indeed come to England in these years, but certainly he never came into conflict with authority. When he came on his diplomatic mission he was warmly welcomed by men close to Cromwell, to some of whom, like Milton, he may have had introductions from scholars abroad. His mission completed, he found himself with a wide circle of acquaintances, among them at least two members of the Boyle family: Katherine, Lady Ranelagh, a friend of Milton's, and her young brother Robert Boyle, not yet known as a natural philosopher. In 1656 he became tutor to Lady Ranelagh's son (he was never a tutor to Henry O'Brien as has been claimed), and spent the next four years on the Continent, whence he sent back a stream of letters, to Boyle and others, showing an increasing involvement with the "new science" of the time. He returned at the Restoration, was quickly elected into the newly formed, still unofficial Royal Society, and, helped greatly by Boyle's patronage, became a Secretary under its first and second Charters. He received irregular remuneration for some years, and an annual salary (of forty pounds a year) from 1668 .

In October 1663 he married one Dorothy West "aged about 40 yeares and a mayden of her owne Disposing," who died at the beginning of February 1664/5. She had some money of her own (400 pounds), administered by two baronets (so she was of a good family), and had possibly but not certainly some connexion with the wife of John Dury. Dury, a Protestant divine who spent most of his life abroad and whom Oldenburg may have known either there or in England, had married in Holland in

\footnotetext{
'Some hitherto unknown facts about the private career of Henry Oldenburg', Notes Rec. R. Soc. Lond., 1963, 18: 94-103.

- See The correspondence of Henry Oldenburg, vol. I, Madison and Milwaukee, University of Wisconsin, 1965, Letter 1, pp. 3-7; and vol. XIII, London, Mansell [in press], Letter la. Oldenburg's surviving correspondence for this period, including that to the Senate of Bremen, is published in Correspondence, vol. 1 .

'Ibid., passim; vol. XIII, Letter 1 bis; vol. XI (London, Mansell, 1977), p. 407.
} 


\section{Short Article}

1645 Dorothy King (d. 1664), widow of Arthur Moore, son of Viscount Moore of Drogheda, and hence connected with many of the great Anglo-Irish families of the time. ${ }^{8}$ At Mrs. Dury's death her daughter, Dora Katherina (1654-77) was entrusted to the Oldenburgs as a ward. It is not clear what happened to the child at the first Mrs. Oldenburg's death, but in August 1668, when she was little more than fourteen years old, she was married to Henry Oldenburg. She it was who brought to Oldenburg the "estate in the marshes of Kent" which he was known to possess - two farms now in Bexley Parish, although Oldenburg always referred to his country retreat as in Crayford, and went there for a late summer holiday in most years. In fact he (and almost immediately his wife) died there in early September 1677, leaving two small children, Rupert and Sophia; their subsequent history is obscure, but Rupert died in pathetic circumstances in 1724, having sold his patrimony to secure a commission in the army in 1699.9

From 1662 to his death in 1677 Oldenburg was the active and industrious "working secretary" of the Royal Society. But he received little remuneration, and although he earned some money as editor and translator for Boyle, he needed more. One source of income came from work he did for Joseph Williamson, then assistant to the Secretary of State, Lord Arlington, later (1674) Secretary himself. In the second charter the Royal Society was given the right to correspond freely with foreign lands, and by 1666 many incoming letters were delivered to the Office of the Secretary of State, where postage was (almost certainly) paid. This was done by the device of having correspondents address their letters simply to "Mr. Grubendol, London", a device which at first puzzled contemporaries as much as it has done historians. Such letters were then sent on, usually unopened, and in return Oldenburg sent political news to Wiiliamson. ${ }^{10} \mathrm{He}$ also utilized this news for various newsletters edited by Williamson, and often served as translator. In 1676 through Williamson he received a warrant to license books, presumably a potentially remunerative post, but he soon relinquished it because he found it led to accusations of disloyalty. "The foundation of the Philosophical Transactions was, as Dr. Farr notes, also intended to be remunerative, but he has confused the issue by assuming that Phil. Trans. R. Soc. came into being with the first issue. The reality is very different indeed. ${ }^{12}$ The Philosophical Transactions: Giving Some Accompt of the Present Undertakings, Studies, and Labours of the Ingenious in many Considerable Parts of the World, clearly indicates by its title that it was not intended to be the "transactions" of the Royal Society alone, but those of the whole world of learning. True, that world persisted in believing that the Transactions had a very close connexion with the Society, a point on which Oldenburg was sensitive. Thus at the end of no. 12 (7 May 1666) he explicitly denied that these were "publish't by the Royal Society"; as was correct, for he was the sole initiator and editor ("publisher" in seventeenth-century terms - or "author" as Oldenburg

'See A. Rupert Hall and Marie Boas Hall, 'Further notes on Henry Oldenburg', Notes Rec. R. Soc. Lond., 1968, 23: 33-42, which discusses the family connexions of Mrs. Dury.

'See ibid., pp. 34, 40-41.

${ }^{10}$ Correspondence, vol. III, pp. 127-128. Oldenburg corresponded with Williamson steadily from 1666.

"Correspondence, vol. XII, Letters 2890 and 2890a.

12 This is clearly brought out in E. N. da C. Andrade, 'The birth and early days of the Philosophical Transactions', Notes Rec. R. Soc. Lond., 1963, 20: 9-27. 


\section{Short Article}

denominated himself in the presentation inscription to the Royal Society of Volume I). Oldenburg's ownership of Phil. Trans. appears clearly in the Minutes of the Council (as published in Birch's History of the Royal Society) as also in the only independent account of its origin, namely a letter from Sir Robert Moray to Christiaan Huygens. ${ }^{13}$ Perhaps it might be added that as late as 1683 when Phil. Trans. appeared after a lapse of four years the editor, Robert Plot, felt it necessary to begin by emphasizing that "the Writing of these Transactions, is not to be looked upon as the Business of the Royal Society ...".14 And indeed Phil. Trans. did not become the official journal of the Society until 1752 (vol. 47).

In the light of these facts, Dr. Farr's account of the spurious no. 27 is inevitably inaccurate. No one had a right to publish Phil. Trans. without Oldenburg's permission. It was no business of Wilkins, whom Dr. Farr believes responsible (he gives no reason, but it was certainly Wilkins - probably acting in his capacity as sole secretary in Oldenburg's absence - who produced the account at the Society's meetings. It seems in fact likely that the original printed letter had been sent to Oldenburg, and even possible that he had made the translation which was published). It was equally no business of the stationer, upon whom Oldenburg laid the blame. ${ }^{15}$ Presumably the stationer tried to distribute it to all those normally subscribing (not, as Dr. Farr surmises, the Fellows of the Society automatically, for it went to anyone who subscribed, and the "free list" was in Oldenburg's private beneficence. There was a print-run of about 500). At any rate the obscure Suffolk physician Nathaniel Fairfax, never F.R.S. although for some years an ardent correspondent of Oldenburg's, had a copy, as he told Oldenburg in September. ${ }^{16}$

It seems possible that Oldenburg had intended to print the letter with editorial comment; certainly he would never have printed it without. But there can be no question of his "suppressing" the false no. 27 in the conventional sense; rather he disowned it, when he came to make up his own next issue.

But why the fuss, which Dr. Farr finds necessary to ascribe to Oldenburg's personal adherence to the English cause? First, as Oldenburg's letter to Boyle already referred to (note 15) makes plain, his reaction was not merely personal; he had been blamed by many and especially by Lower for printing Denis' claim to have instituted transfusion ten years earlier, in defiance of English claims for priority. What justification was there for this feeling, unless it merely resulted from English xenophobia? That certainly did exist, and accounts, for example, for such claims as that put forward by Dr. Timothy Clarke in 1668, that the idea of blood transfusion had first been suggested by Francis Potter (F.R.S. 1663) about 1639.17 What is more certain, as Clarke went on to say, is that in 1656 Christopher Wren and others had begun experiments on the injection of "various liquors into the mass of the blood of living animals"

${ }^{13}$ Oeuvres completes de Christiaan Huygens, vol. V, The Hague, Nijhoff, 1893, p. 232.

14 No. 143 of January 1682/3.

is See for example Oldenburg's letter to Boyle of 24 September 1667, Correspondence, vol. III, pp. 480, 483 , note 2 .

${ }^{16}$ Letter of 28 September 1667, Correspondence, vol. III, p. 497.

${ }^{17}$ Correspondence, vol. IV, pp. 364-365; John Aubrey in his Brief life of Potter said the same. For another claim for English priority see John Wallis to Oldenburg, Correspondence, vol. III, p. 373. 
as Clarke put it, and Clarke claimed to have tried various experiments himself in 1657. The first transfusion of blood from one animal to another (dogs) was performed by Richard Lower in late 1665 and an account read at the Royal Society some six months later. ${ }^{18}$ Lower published an account of his experiments to justify his claim to priority since "a certain Denis, seeks in a recently published letter to deprive me of priority in the discovery of this experiment, and to claim it for himself." There can be no question but that Lower had performed the transfusion experiments in dogs when he claimed to have done so, nor that this preceded French work. When on 21 March $1666 / 7$ Oldenburg at a meeting of the Society produced an account "which he had received from Paris, of the success, which the curious had met with there" it was because there was a lively discussion going on the same subject; and there were endless further discussions in subsequent months.

There can therefore be no doubt that in animal transfusion the English were right to claim priority. Equally there is no doubt that the French were the first rashly to venture on human transfusion, which the English did not attempt until late November 1667. (To the credit of the physician in charge of Bedlam he "scrupled" to expose his patients to the ordeal when it was earlier proposed to him.) ${ }^{20}$ Oldenburg was clearly right to set the record straight in his Philosophical Transactions, nor could he have faced his colleagues and fellow members of the Royal Society had he failed to repudiate responsibility for the false Phil. Trans. no. 27. But neither he nor the Society was otherwise hostile to Denis, with whom Oldenburg was to correspond freely in $1668 .{ }^{21}$ At that time Oldenburg in fact published translations of two of Denis' printed letters on the subject (one addressed to himself) without arousing any further reactions from the Society: these are straightforward accounts of events - including the death of one of the human recipients of animal blood, and the judgment of the Paris court thereon - and involve no questions of priority.

The English at this period were, to say the least, touchy about questions of national prestige and priority in scientific discovery, and in many cases it is difficult to arrive at the truth. But here it seems that their claims were clearly justified, and Lower quite rightly resentful of Denis' claim. No wonder that Oldenburg repudiated the false Phil. Trans., as he probably would have done even if no question of national prestige had been involved, since the Philosophical Transactions were his private enterprise, and his standards as editor high.

\footnotetext{
${ }^{18}$ Meeting of 20 June 1666. See T. Birch, History of the Royal Society' of London, 4 vols., London, 1756 , vol. II. There is a more detailed account in the letter from Boyle to Lower printed (pp. 177-179) in the latter's Tractatus de corde, London, 1669, reprinted, with English translation, in vol. IX of R. T. Gunther (editor), Early science in Oxford, Oxford, [The Author], 1932, and London, Dawson, 1968. Lower's account of his work on transfusion is in ch. 4.

${ }^{19}$ Birch, op. cit., note 18 above, vol. II, p. 161.

${ }^{20}$ Minutes of the Royal Society's meeting of 31 October 1667.

21 There is no evidence for Dr. Farr's surmise that the two were in correspondence in 1667. It is not known precisely who in Paris received Phil. Trans. at this time, other than Henri Justel, the editor of the Journal des Sçavans, and Christiaan Huygens, but several copies were in circulation.
} 